\title{
Predictive equation of metastasis in patients with malignant ovarian epithelial tumors with the Ca-125 marker
}

\author{
Juan Fernando Sánchez Vega ${ }^{1}$, Magdali del Rocío Murillo Bacilio ${ }^{2,3}$, Adrián Santiago Vintimilla Condoy ${ }^{1}$, \\ Araceli Miroslava Palta González ${ }^{2,4}$, José Alfredo Crespo Astudillo ${ }^{5}$ and Franklin Geovany Mora-BravoMsC ${ }^{3 *}$ (D
}

\begin{abstract}
Background: Cancer antigen (CA) 125 (CA-125) is used in ovarian cancer detection and monitoring, whose serum level has a positive correlation with tumor stage. The aim of this study was to obtain a prediction metastasis equation in a group of patients with ovarian cancer based on Ca-125.

Methods: A 2-group comparative observational study was conducted at a single oncologic institution (SOLCA) in Cuenca-Ecuador. All patients who were diagnosed with ovarian cancer between January 1996 and December 2016 were included in the current study. Group 1 (G1) patients with the I and II International Federation of Gynecology and Obstetrics (FIGO) stage and Metastasis Group (MG), with III and IV stage, were subdivided. A logistic regression equation was performed to predict metastasis based on Logarithm of serum Ca-125 levels.

Results: We included 85 cases in $G 1$ and 64 patients in MG, with $47.8 \pm 15$ years (G1) and $57.5 \pm 13.6$ years (MG) of age $(P<0.001)$. Mortality in $G 1$ was 2 cases $(3.1 \%)$ and 53 cases $(62.4 \%)$ in $M G(P<0.001)$. The $C A-125$ serum level was $163.5 \pm 236$ in $\mathrm{Gl}$ and $1220.9 \pm 1940 \mathrm{u} / \mathrm{ml}$ in MG $(P<0.001)$. The equation to predict metastasis $=\left(\right.$ Age $\left.{ }^{*} 0.053\right)$ $+\left[(\text { Logarithm Ca-125 value })^{*} 1.078\right]-8.163$ with an OR $2.940(\mathrm{Cl} 95 \%$ 2.046-4.223) $P<0.001$. The sensitivity of the equation was $82.4 \%$ and the specificity was $79.7 \%$.
\end{abstract}

Conclusions: It is possible to predict the presence of metastasis in a group of patients with ovarian cancer based on Ca-125.

Keywords: Prediction of metastasis, Ovarian Cancer, Cancer antigen 125

\section{Background}

Ovarian cancer is one of the ten leading causes of death worldwide, this pathology occurs in all ages including childhood and adolescence, most cases are diagnosed in very advanced stages [1]. In the detection and monitoring of ovarian cancer, the tumor marker $\mathrm{Ca}-125$ is used, but because of its low sensitivity (70\%) and specificity (90\%) [2], it is used in conjunction with other methods such as imaging such as transvaginal doppler ultrasound $[3,4]$, improving the diagnosis up to $90 \%$ of cases of ovarian cancer $[4,5]$. On the other hand, it has been used as a prognostic factor for recurrence and survival,

\footnotetext{
* Correspondence: franklin.mora@ucuenca.edu.ec

${ }^{3}$ School of Medicine, University of Cuenca, Av. 12 de abril and Paraíso Street, 010201 Cuenca, Ecuador

Full list of author information is available at the end of the article
}

as well as an indicator of disease progression [6], there being a relationship between the tumor stage and the increase in the value of Ca-125 [7]. The level of normality of Ca-125 has been standardized in: less than $35 \mathrm{IU} / \mathrm{ml}$ in the postmenopause [8] and $65 \mathrm{IU} / \mathrm{ml}$ in the premenopause [3]. The majority of primary ovarian neoplasms originate in the Müller epithelium [9]. The classification is based on the differentiation and extension of epithelial proliferation, with three main histological types: Serous, Mucinous and Endometrioid [10]. Depending on the type of ovarian cancer, differences in serum concentration are observed, for example abnormal levels of Ca-125 are observed in $99 \%$ of serous carcinoma cases classified from I to IV in the progression of their clinical stage. Patients with clinical stage I serous carcinoma show normal values of $\mathrm{Ca}-125$ in $11 \%$ of cases, while in

(c) The Author(s). 2018 Open Access This article is distributed under the terms of the Creative Commons Attribution 4.0 International License (http://creativecommons.org/licenses/by/4.0/), which permits unrestricted use, distribution, and reproduction in any medium, provided you give appropriate credit to the original author(s) and the source, provide a link to the Creative Commons license, and indicate if changes were made. The Creative Commons Public Domain Dedication waiver (http://creativecommons.org/publicdomain/zero/1.0/) applies to the data made available in this article, unless otherwise stated. 
clinical stage IV, all patients with serous subtype show abnormal Ca-125 values. The total proportion of abnormal Ca-125 values (stages I to IV) was $89 \%$ in the endometrioid subtype of ovarian carcinoma, while patients with FIGO stage I endometrioid carcinoma showed 19\% of $\mathrm{Ca}$ levels. - 125 normal. As in the serous subtype, endometrioid ovarian carcinoma shows $100 \%$ abnormal Ca-125 in clinical stage IV [4]. There is a relationship between the tumor stage and the increase in the value of Ca-125, with $50 \%$ of patients in stage I having an increase, $75 \%$ in stage II, 90\% in stage III and 98\% in Stage IV [7]. There is a need to establish an index to improve cancer care in low/middle income countries where there is limited/no availability of cross-sectional imaging - an accurate index would facilitate triage of patients to a facility with the necessary oncological expertise for optimal surgery and/or chemotherapy (including potentially neo-adjuvant chemo). With this background, the present study aims to perform an equation to predict patients with ovarian cancer who have metastasized on the basis of $\mathrm{Ca}-125$ as a predictor variable.

\section{Methods}

The present in an observational study conducted at the Cancer Institute SOLCA in the city of Cuenca - Ecuador, province of Azuay. Clinical histories of patients diagnosed with Ovarian Cancer who were treated in the 1996-2016 period were reviewed. Cases with insufficient data were excluded for the analysis. We collected demographic variables, type of ovarian cancer, stage and serum levels of Ca-125. The classification of the stages was the one adopted by the FIGO [11] described below to form the study groups:

Group 1: patients with stage I and II.

Group 2: patients with stage III and IV.

Stage I: Stage in which the tumor is confined to the ovaries.

Stage II: Stage in which the tumor involves one or both ovaries, with extension adjacent to pelvic tissues.

Stage III: The tumor involves one or both ovaries, with cytology or confirmed histology of spreading out of the pelvis and with metastases to the retro peritoneum and / or lymph nodes.

Stage IV: Advanced stage of cancer in which there is metastasis confirmed at a distance that excludes peritoneal metastasis.

The analysis of post-harvest information was tabulated and processed using the IBM SPSS Statistics license-free software updated to version 15.0. For the analysis of qualitative variables such as sex, residence, histological type, stage, value of Ca-125 and associated factors, a distribution of relative and absolute frequencies was
Table 1 Demographic data and background of the study groups

\begin{tabular}{|c|c|c|c|}
\hline & $\begin{array}{l}\text { Group 1Stages } \\
\text { I \& II-FIGO }\end{array}$ & $\begin{array}{l}\text { Group } 2 \text { Advanced } \\
\text { ovarian cancer group } \\
\text { Stages III \& IV-FIGO }\end{array}$ & $P$ \\
\hline & $n=85$ & $n=64$ & \\
\hline \multicolumn{4}{|l|}{ Civil Status } \\
\hline Single & 20 (23.5\%) & 17 (26.6\%) & 0.829 \\
\hline Free union & $3(3.5 \%)$ & $3(4.7 \%)$ & \\
\hline Married & $42(49.4 \%)$ & 34 (53.1\%) & \\
\hline Divorcee & $4(4.7 \%)$ & $2(3.1 \%)$ & \\
\hline Widow & $16(18.8 \%)$ & $8(12.5 \%)$ & \\
\hline \multicolumn{4}{|l|}{ Place of residence } \\
\hline Cuenca & $39(45.9 \%)$ & $24(37.5 \%)$ & 0.399 \\
\hline Machala & $9(10.6 \%)$ & $4(6.3 \%)$ & \\
\hline Gualaceo & $3(3.5 \%)$ & $1(1.6 \%)$ & \\
\hline Paute & $1(1.2 \%)$ & $3(4.7 \%)$ & \\
\hline Azogues & $5(5.9 \%)$ & 7 (10.9\%) & \\
\hline Others & $28(32.9 \%)$ & 25 (39.1\%) & \\
\hline $\begin{array}{l}\text { Cancers Family } \\
\text { Antecedents }\end{array}$ & $20(23.5 \%)$ & $18(28.1 \%)$ & 0.524 \\
\hline $\begin{array}{l}\text { Breast Cancer Family } \\
\text { History }\end{array}$ & $4(4.7 \%)$ & $6(9.4 \%)$ & 0.493 \\
\hline $\begin{array}{l}\text { Hormonal Therapy } \\
\text { History }\end{array}$ & $3(3.5 \%)$ & $3(4.7 \%)$ & 0.722 \\
\hline \multicolumn{4}{|l|}{ Biological state } \\
\hline $\begin{array}{l}\text { Premenopausal vs } \\
\text { Postmenopausal }\end{array}$ & $20(23.5 \%)$ & $27(42.2 \%)$ & 0.015 \\
\hline
\end{tabular}

performed. For analysis of the relationship between the value of Ca-125 versus age, histological type, stage and associated factors, we used chi-square and bivariate analysis. CA-125 value was transformed into a logarithm of base "e" for the regression eq. $P$ values less than 0.05 were considered statistically significant. Logistic regression was performed between the groups of Stages I and II versus Stages III and IV to predict the presence of the last stages using $\mathrm{Ca}-125$. The project did not imply any risk for the patients since we worked on clinical history only and this report ensures the confidentiality of

Table 2 Histological type of Ovary Cancer in the study groups

\begin{tabular}{llll}
\hline Variable & $\begin{array}{l}\text { Group 1 Stages } \\
\text { I \& II-FIGO } \\
n=85\end{array}$ & $\begin{array}{l}\text { Group 2 Advanced ovarian } \\
\text { cancer group Stages III \& } \\
\text { IV-FIGO } \\
n=64\end{array}$ & $P$ \\
\hline $\begin{array}{l}\text { Histological type } \\
\text { Serous }\end{array}$ & $75(88.2 \%)$ & $46(71.9 \%)$ & 0.024 \\
Mucinous & $9(10.6 \%)$ & $10(15.6 \%)$ & \\
Endometroid & 0 & $5(7.8 \%)$ & $1(1.6 \%)$ \\
Clear cells & $1(1.2 \%)$ & $2(3.1 \%)$ \\
Transitional cells & 0 & &
\end{tabular}


Table 3 Binary logistic regression between Metastasis and Ca-125 logarithm

\begin{tabular}{|c|c|c|c|c|c|c|c|c|}
\hline & \multirow[t]{2}{*}{ B } & \multirow[t]{2}{*}{ S.E. } & \multirow[t]{2}{*}{ Wald } & \multirow[t]{2}{*}{$d f$} & \multirow[t]{2}{*}{ Sig. } & \multirow[t]{2}{*}{$\operatorname{Exp}(B)$} & \multicolumn{2}{|c|}{ 95\% C.I.for EXP(B) } \\
\hline & & & & & & & Lower & Upper \\
\hline \multicolumn{9}{|l|}{ Step $2^{a}$} \\
\hline Age & 0.053 & .015 & 11.847 & 1 & 0.001 & 1.054 & 1.023 & 1.087 \\
\hline LOG CA-125 & 1.078 & .185 & 34.010 & 1 & $<0.0001$ & 2.940 & 2.046 & 4.223 \\
\hline Constant & -8.163 & 1.415 & 33.295 & 1 & $<0.0001$ & 0.000 & & \\
\hline
\end{tabular}

${ }^{a}$ Variable(s) entered on step 1: Age, LOG CA.125

identity and the management of the database. The Bioethics Committee of the Cancer Institute SOLCA-Cuenca approved the present study as well as obtaining the permission of the director of the Hospital.

\section{Results}

In the study, 149 cases were enrolled, of which 85 patients were classified as having ovarian cancer without metastasis and 64 patients in the metastasis group. The mean age of the group without metastasis was $47.8 \pm$ 15 years and the group without metastasis was $57.5 \pm$ 13.6 years $(P<0.001)$. With a median of 4 pregnancies in group 1 with an interquartile range of 5 and with 4 pregnancies and an interquartile range of 5 in group $2(P=$ 0.796). There were no differences between marital status and place of residence between the groups (Table 1). Additionally, the family history of cancer was not different between the groups (Table 1). The histological type of ovarian cancer predominant in both groups was serous (Table 2), with a greater group of women in premenopause in group 1 (Table 1 ). In group 1 there were 52 patients $(81.3 \%)$ in Stage I and 12 patients (18.8\%) in stage II, in group 2 there were 49 patients $(57.6 \%)$ in stage III and 36 patients (42.4\%) in stage IV. Mortality in group 2 was higher than in group 1 (Table 2). The Ca-125 antigen was positive in 42 cases in group 1 $(65.6 \%)$ and in 79 cases $(92.9 \%)$ in group $2(P<0.001)$, with an average of $163.5 \pm 236 \mathrm{u} / \mathrm{ml}$ in group 1 and of $1220.9 \pm 1940 \mathrm{u} / \mathrm{ml}$ in group $2(P<0.001)$.

\section{Metastasis probability}

The metastasis probability $(\geq 0.50)$ was established as:

$$
P=\frac{1}{1+\exp ^{-F}}
$$

Where $\mathrm{F}$ is the logistic regression equation (Table 3 and Additional file 1):

$\mathrm{F}=($ Age*0.053) $+[$ (logarithm of Ca-125) *1.078 $]-8.163$.

Were excluded non-significant variables named: "Pregnancies number" and biological status "Menopause" (Table 4). An internal validation was performed with the bootstrap method (Table 5).

\section{Diagnostic test of the metastasis prediction equation}

A $2 \times 2$ contingency table was constructed. The data of groups 2 and 1 were placed in columns and the metastasis prediction equation in rows (Presence and Absence). Table values were (a) 70 cases (b) 13 cases, (c) 15 cases and (d) 51 cases. This table reported a sensitivity of $82.4 \%$, and a specificity of $79.7 \%$. The positive predictive value of $84.3 \%$ and the negative predictive value of $77.2 \%$. The positive likelihood ratio was 4.059 and the negative likelihood ratio was 0.22 . The ROC curve reported an Area under the curve of 0.870 (95\% CI $0.812-0.928)$ with a standard error of 0.03 and $P<0.0001$ (Fig. 1).

\section{Discussion}

The main finding of the present study was that high levels of Ca-125 are related to the presence of metastases in this group of patients diagnosed with Ovarian Cancer. The Odds Ratio of this relationship is 2.940 (CI 95\% 2.046-4.223) $P<0.001$ (Table 3), the logistic regression equation was statistically significant and establishes the serum level of Ca-125 as a statistically significant

Table 4 Binary logistic regression between Metastasis and Ca-125 logarithm, Age, Pregnancies number, Menopause

\begin{tabular}{|c|c|c|c|c|c|c|c|c|}
\hline & \multirow[t]{2}{*}{$B$} & \multirow[t]{2}{*}{ S.E. } & \multirow[t]{2}{*}{ Wald } & \multirow[t]{2}{*}{ df } & \multirow[t]{2}{*}{ Sig. } & \multirow[t]{2}{*}{$\operatorname{Exp}(B)$} & \multicolumn{2}{|c|}{ 95\% C.I. for EXP(B) } \\
\hline & & & & & & & Lower & Upper \\
\hline \multicolumn{9}{|l|}{ Step $1^{\text {a }}$} \\
\hline Age & 0.096 & 0.028 & 11.656 & 1 & 0.001 & 1.101 & 1.042 & 1.163 \\
\hline Pregnancies number & -0.098 & 0.083 & 1.406 & 1 & 0.236 & .907 & .771 & 1.066 \\
\hline LOG CA-125 & 1.034 & 0.185 & 31.236 & 1 & $<0.0001$ & 2.812 & 1.957 & 4.040 \\
\hline Premenopause/Menopause [1] & 1.240 & 0.736 & 2.843 & 1 & 0.092 & 3.457 & .818 & 14.619 \\
\hline Constant & -10.27 & 1.975 & 27.045 & 1 & $<0.0001$ & .000 & & \\
\hline
\end{tabular}

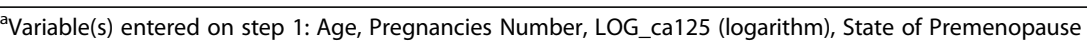


Table 5 Bootstrap for Variables in the Equation

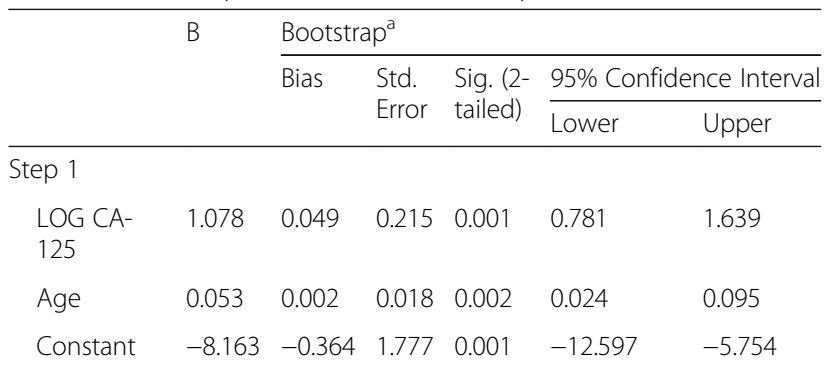

${ }^{a}$ Bootstrap results are based on 1000 bootstrap samples

predictor of the presence of metastasis. The equation had a positive predictive value of $84.3 \%$ with a positive likelihood ratio of 4.059. The ROC Curve reported an Area under the curve of 0.87 which was statistically significant. The cut-off point of the Ca- 125 value to predict the presence of metastases in this study group was $240 \mathrm{u}$ / $\mathrm{ml}$. In the equation, non-prognostic variables were excluded, such as the fact of dying, and spurious variables such as family history and origin were excluded. The significance of finding an association between the stage of metastasis (State II and III of the FIGO classification) and the serum levels of $\mathrm{Ca}-125$ allows us to have a practical and applicable equation in daily clinical practice. It has been established that the serum levels of Ca-125 pretreatment are increased, showing a positivity of $55 \%$ in the serous types, and between 42 to $77 \%$ in stage III [4] and stage IV (15\%), being these mostly serous epithelial type [12]. In the present study, serous epithelial

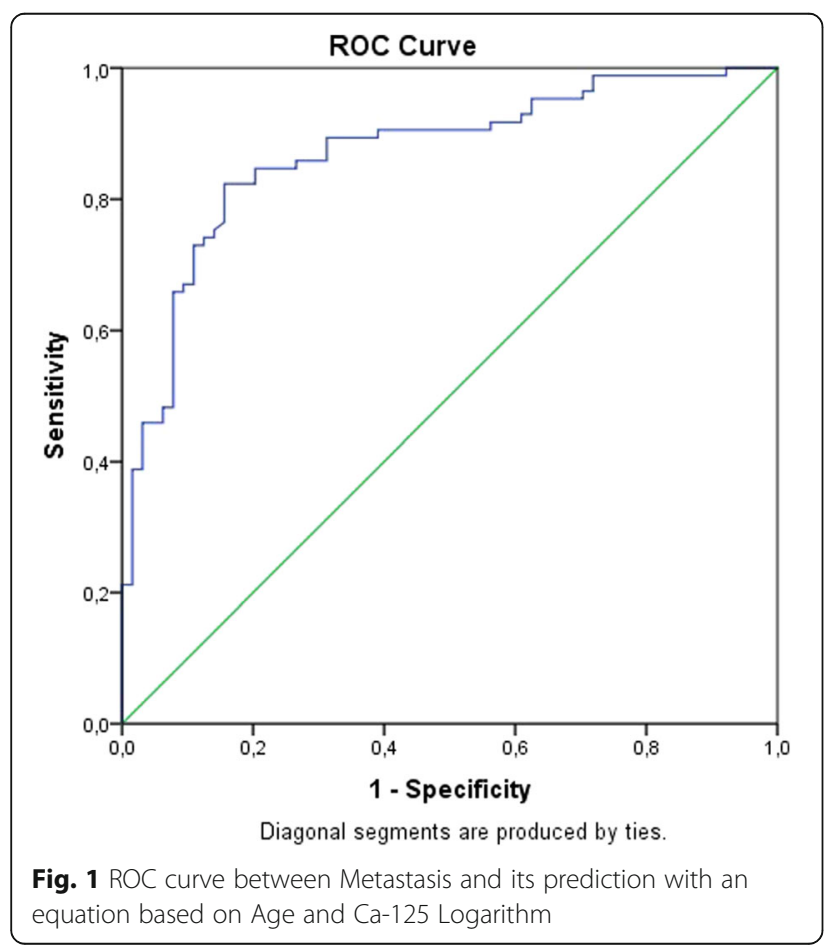

cancer was predominant (81.2\%), and most of it was in stage III, which coincides with FIGO statistics [13] due to late diagnosis [14]. In the study it was found that the stage with the highest elevation of the marker was stage III (36.4\%), this may be due to the fact that in advanced stages there is metastasis, while in the histological type it was the serous (85.27\%), significant statistical relationship observed in other studies [14] however in no previous work an equation has been established to predict metastasis as in the present study. It has been shown that the association between Metastasis in patients with ovarian cancer and serum $\mathrm{Ca}-125$ levels fits into the causality, since the tumor burden is intruded. The relationship is less associated with stages in which the load or tumor mass has been decreased in therapeutic form and may be an alternative explanation to the reason for decreasing the association with advanced stages already operated therapeutically. In daily practice, the equation helps to quickly predict the state of metastasis of patients and finally the mortality since the group with metastasis had higher mortality than the group without metastasis. This study does not include other tumor markers used in ovarian cancer. Future research should prospectively address the prediction equation to predict metastasis and compare it with a gold standard clinical.

\section{Conclusions}

There is a relationship between the clinical stage of metastasis and serum Ca-125 levels in this group of patients with ovarian cancer.

\section{Additional files}

Additional file 1: Excel sheet for calculating the probability of ovarian cancer metastasis. (XLSX $9 \mathrm{~kb}$ )

Additional file 2: Database in Excel format. (XLSX 19 kb)

\section{Abbreviations}

CA-125: Cancer antigen 125; FIGO: International Federation of Gynecology and Obstetrics

\section{Acknowledgements}

Acknowledgment to the SOLCA-workers who participated indirectly in the study. Acknowledgment to Bernardo Vega, Dean of the Faculty of Medical Sciences of the School of Medicine for the economic management for financing.

Funding

The economic source of this research and publication was provided by School of Medicine at the University of Cuenca. I clarify that the funds allocated by the University of Cuenca did not participate in the design of the study, data collection, analysis, interpretation of the data or in the writing of the manuscript. The funds were allocated solely for the translation of the manuscript and to cover the costs of publishing the article.

\section{Availability of data and materials}

The data supporting the findings of this study are available upon request from the main author. The database is attached in Additional file 2. 


\section{Authors' contributions}

Research Idea: JFSV, MRMB, FGMB. Study design: JFSV, ASVC, AMPG, FGMB.Bibliographic review: JFSV, ASVC, JACR. Data collection: JFSV, ASVC, JACRHealing of the data: MRMB. Data analysis: FGMB. Draft writing: JFSV. Critical analysis of the document: MRMB, AMPG, FGMB. All authors read and approved the final version of the article.

\section{Authors' information}

Juan Fernando Sánchez Vega: Rural Doctor Ministry of Public Health of Ecuador. Av May 1st 357 and Carlos Quinto. jfsanchezvega@icloud.com orcid.org/0000-0003-1582-4638

Magali del Rocío Murillo Bacilio. rocimurillo4@yahoo.com.mx Affiliation: Medical Pathologist from the Department of Pathology SOLCA-Cuenca. Professor of Pathology at the school of medicine, University of Cuenca. orcid.org/0000-0003-3183-7906

Adrián Santiago Vintimilla Condoy. a.dri_an@hotmail.com Rural Doctor Ministry of Public Health of Ecuador. orcid.org/0000-0002-7016-2262 Araceli Miroslava Palta González aracelimpg@hotmail.com Medical Pathologist from the Department of Pathology SOLCA-Cuenca. Head of Department. orcid.org/0000-0003-0516-1172

José Alfredo Crespo Astudillo. Resident Doctor Pablo Jaramillo Foundation. Franklin Mora-Bravo, MD, MsC. Main professor of nephrology at the school of medicine, University of Cuenca. Master's degree in health research.orcid.org/ 0000-0002-5978-3420

\section{Ethics approval and consent to participate}

The research protocol was approved by the bioethics committee of the University of Cuenca and the Bioethics Committee of the SOLCA-Cuenca Institute. A written consent to participate was requested to study patients. Only participants who signed the informed consent forms were included in the study.

\section{Competing interests}

The authors declare that they have no competing interests.

\section{Publisher's Note}

Springer Nature remains neutral with regard to jurisdictional claims in published maps and institutional affiliations.

\section{Author details}

${ }^{1}$ Rural Doctor Ministry of Public Health of Ecuador, Zone 6, Cuenca, Ecuador. ${ }^{2}$ Department of Pathology of the Institute for the Fight against Cancer Society -SOLCA-Cuenca, Cuenca, Ecuador. ${ }^{3}$ School of Medicine, University of Cuenca, Av. 12 de abril and Paraíso Street, 010201 Cuenca, Ecuador. ${ }^{4}$ School of Medicine, University of Azuay, Cuenca, Ecuador. ${ }^{5}$ Pablo Jaramillo Foundation, Complementary Health Network, Cuenca, Ecuador.

Received: 29 January 2018 Accepted: 10 May 2018

Published online: 24 May 2018

\section{References}

1. Trétarre B, Molinié F, Woronoff AS, Bossard N, Bessaoud F, Marrer E, et al. Ovarian cancer in France: trends in incidence, mortality and survival, 19802012. Gynecol Oncol. 2015;139(2):324-9. https://doi.org/10.1016/j.ygyno. 2015.09.013

2. Coussy F, Chéreau E, Daraï E, Dhombres F, Lotz JP, Rouzier R, et al. Interest of CA 125 level in management of ovarian cancer. Gynecol Obstet Fertil. 2011;39(5):296-301. https://doi.org/10.1016/j.gyobfe.2010.10.018.22.

3. Paul P, Talukder S, Sangma MA, Saha PL, Begum M, Razi AZ, et al. Detection of ovarian tumor by color Doppler ultrasonography and CA-125. Mymensingh Med J. 2017;26(4):705-9. PubMed PMID: 29208855.

4. Morales-Vásquez F, Pedernera E, Reynaga-Obregón J, López-Basave HN, Gómora MJ, Carlón E, et al. High levels of pretreatment CA125 are associated to improved survival in high grade serous ovarian carcinoma. J Ovarian Res. 2016;9:41. Available from: http://www.ncbi.nlm.nih.gov/pmc/ articles/PMC4936203/.

5. Varras M. Benefits and limitations of ultrasonographic evaluation of uterine adnexal lesions in early detection of ovarian cancer. Clin Exp Obstet Gynecol. 2004;31(2):85-98. Review. PubMed PMID: 15266758.

6. Dolores-Velázquez R, Bustamante-Montes LP, Romero-Fierro JR, Gómez-Plata E, Ocampo-García KG, Dueñas-González A. Relación entre niveles de CA-125 y características clínicas e histopatológicas en el cáncer epitelial de ovario. Gac Mex Oncol. 2014;13(4):207-14.

7. Tiwari RK, Saha K, Mukhopadhyay D, Datta C, Chatterjee U, Ghosh TK. Evaluation of preoperative serum levels of CA 125 and expression of p53 in ovarian neoplasms: a prospective Clinicopathological study in a tertiary care hospital. J Obstet Gynaecol India. 2016;66(2):107-14. https://doi.org/10.1007/ s13224-014-0611-7.

8. Schmidt C. CA-125: a biomarker put to the test. J Natl Cancer Inst. 2011; 103(17):1290-1.

9. Worzfeld T, Pogge von Strandmann E, Huber M, Adhikary T, Wagner U, Reinartz S, Müller R. The unique molecular and cellular microenvironment of ovarian Cancer. Front Oncol. 2017;7:24. https://doi.org/10.3389/fonc.2017.00024.

10. Hauptmann S, Friedrich K, Redline R, Avril S. Ovarian borderline tumors in the 2014 WHO classification: evolving concepts and diagnostic criteria. Virchows Arch. 2017:470(2):125-42. https://doi.org/10.1007/s00428-016-2040-8

11. Prat J, Belhadj H, Berek J, Bermudez A, Bhatla N, Cain J, et al. Staging classification for cancer of the ovary, fallopian tube, and peritoneum. Int Gynaecol Obstet. 2014;124(1):1-5. https://doi.org/10.1016/j.ijgo.2013.10.001.

12. Willis $\mathrm{S}$, Villalobos VM, Gevaert $\mathrm{O}$, Abramovitz M, Williams C, Sikic Bl, et al. Single gene prognostic biomarkers in ovarian Cancer: a meta-analysis. PLoS One. 2016;11(2):e0149183.

13. Prat J. FIGO's staging classification for cancer of the ovary, fallopian tube, and peritoneum: abridged republication. J Gynecol Oncol. 2015;26(2):87-9. https://doi.org/10.3802/jgo.2015.26.2.87.

14. Zivanovic O, Sima C, lasonos A, Bell-McGuinn K, Sabbatini P, Leitao M, et al. Exploratory analysis of serum CA-125 response to surgery and the risk of relapse in patients with FIGO stage IIIC ovarian Cancer. Gynecol Oncol. 2009;115(2):2-17. https://doi.org/10.1016/j.ygyno.2009.06.038.

\section{Ready to submit your research? Choose BMC and benefit from:}

- fast, convenient online submission

- thorough peer review by experienced researchers in your field

- rapid publication on acceptance

- support for research data, including large and complex data types

- gold Open Access which fosters wider collaboration and increased citations

- maximum visibility for your research: over $100 \mathrm{M}$ website views per year

At BMC, research is always in progress.

Learn more biomedcentral.com/submissions 